\title{
Cis-guggulsterone inhibits the IKK/NF-кB pathway, whereas trans-guggulsterone inhibits MAPK/AP-1 in MCF-7 breast cancer cells: Guggulsterone regulates MMP-9 expression in an isomer-specific manner
}

\author{
EUN-MI NOH ${ }^{1 *}$, EUN YONG CHUNG ${ }^{2 *}$, HYUN JO YOUN ${ }^{3}$, SUNG HOO JUNG ${ }^{3}$, \\ HYUN HUR $^{1}$, YOUNG-RAE LEE ${ }^{4}$ and JONG-SUK KIM ${ }^{1}$
}

\begin{abstract}
${ }^{1}$ Department of Biochemistry and Institute for Medical Sciences, Chonbuk National University Medical School, Jeonju 560-182; ${ }^{2}$ Department of Anesthesiology and Pain Medicine, Bucheon St. Mary's Hospital, Catholic University of Korea, Bucheon 420-717; ${ }^{3}$ Department of Surgery, Division of Breast-Thyroid Surgery, Chonbuk National University Medical School, Jeonju 560-182; ${ }^{4}$ Department of Oral Biochemistry, School of Dentistry, Wonkwang University, Iksan 570-749, Republic of Korea
\end{abstract}

Received August 24, 2012; Accepted October 22, 2012

DOI: $10.3892 /$ ijmm.2012.1214

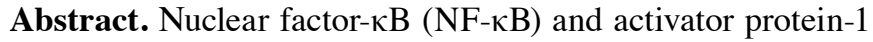
(AP-1) are major transcription factors that have been associated with breast cancer metastasis by inducing matrix metalloproteinase-9 (MMP-9) expression. In this study, we investigated the inhibitory effects of guggulsterone isomers (cis or trans) on 12- $O$-tetradecanoylpho-bol-13-acetate (TPA)-induced MMP-9 expression. Cis-guggulsterone inhibited TPA-induced MMP

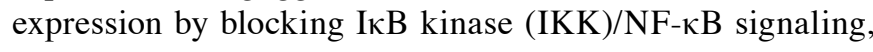
whereas trans-guggulsterone blocked mitogen-activated protein kinase (MAPK)/AP-1 signaling. Cis-guggulsterone was more potent than trans-guggulsterone in the inhibition of TPA-induced MMP-9 expression and invasion of MCF-7 cells. Furthermore, we found that the combination of these isomers exerted an additive effect on the inhibition of MCF-7 cell invasion. These results suggest that guggulsterone isomers
\end{abstract}

Correspondence to: Professor Young-Rae Lee, Department of Oral Biochemistry, School of Dentistry, Wonkwang University, 460 Iksandae-ro, Iksan 570-749, Republic of Korea

E-mail:mindyr@wku.ac.kr

Professor Jong-Suk Kim, Department of Biochemistry and Institute for Medical Sciences, Chonbuk National University Medical School, San 2-20 Keumam-dong, Jeonju 560-182, Republic of Korea

E-mail: jsukim@jbnu.ac.kr

*Contributed equally

Abbreviations: TPA, 12-O-tetradecanoylpho-bol-13-acetate; MMP, matrix metalloproteinase; IKK, I- $\kappa \mathrm{B}$ kinase; AP-1, activator protein-1; MAPK, mitogen-activated protein kinase; ECM, extracellular matrix

Key words: guggulsterone, nuclear factor- $\mathrm{B}$, activator protein-1, matrix metalloproteinase-9, $\mathrm{MCF}-7$ downregulate MMP-9 expression and tumor cell invasion through the isomer-specific suppression of IKK/NF- $\kappa B$ and MAPK/AP-1 activation. In addition, the suppression of MMP-9 expression correlated well with the inhibition of cell invasion.

\section{Introduction}

Guggulsterone [4,17(20)-pregnadiene-3,16-dione], is a plant sterol derived from the gum resin (guggulu) of the tree Commiphora mukul. This gum resin has been used for centuries in Ayurvedic medicine to treat obesity, arthritis and hyperlipidemia $(1,2)$. The anti-arthritic, anti-inflammatory and anti-lipid activities of guggulsterone have also been demonstrated (3). Recently, guggulsterone has been shown to exhibit antitumor activity in a variety of human tumor cell types (4). The active compound in the resin is cis and trans isomers of guggulsterone $(3,5)$. Of note, cis-guggulesterone is more potent than the trans-isomer in inducing apoptosis in mature adipocytes (3). Furthermore, guggulesterone isomers have been shown to exhibit isomer-specific antitumor activity (6-8). However, the molecular mechanism of guggulesterone-mediated anticancer activity remains elusive.

Invasion processes require the degradation of the extracellular matrix (ECM), which provides biochemical and mechanical barriers to cell movement in cancer (9). Studies have reported that in the matrix metalloproteinase (MMP) family, gelatinases A (72 kDa gelatinase, type IV collagenase and MMP-2) and B (92 kDa gelatinase, type IV collagenase and MMP-9) play a critical role in ECM degradation and cell migration leading to tumor cell invasion in breast cancer $(10,11)$. Elevated MMP-9 levels have been functionally linked to elevated metastasis in a number of tumor types, such as brain (12), prostate (13), bladder (14) and breast tumors $(15,16)$. Consequently, inhibiting the expression of MMP-9 and/or its upstream regulatory pathways may prove to be effective in treating malignant tumors, including breast cancer. 
Protein kinase $\mathrm{C}(\mathrm{PKC})$ is involved predominantly in the production of MMP-9 (17-21). A PKC activator, 12-Otetradecanoylpho-bol-13-acetate (TPA), induces MMP-9 synthesis and secretion during various pathological processes, such as tumor invasion (16,22). TPA-mediated MMP-9 expression is regulated by activating transcription factors, such as nuclear factor- $\kappa \mathrm{B}(\mathrm{NF}-\kappa \mathrm{B})$ and activator protein-1 (AP-1) in cancer cells (23-25). The mitogen-activated protein kinase (MAPK) signaling pathway is important for AP-1 activation and $\mathrm{NF}-\kappa \mathrm{B}$ activation requires I $\mathrm{B}$ kinase (IKK), phosphoinositide 3 kinase-Akt, or p38 MAPK, depending on the cell type (17-21). Consequently, these findings suggest that the main pathways involved in MMP-9 expression following PKC activation are the MAPK, NF- $\kappa$ B and AP-1 pathways.

In this study, we investigated the roles of guggulsterone isomers in regulating TPA-induced MMP-9 expression, and thus suppressing cell invasion, as well as the mechanisms involved.

\section{Materials and methods}

Cells and materials. MCF-7 cells were obtained from the American Type Culture Collection (Manassas, VA, USA). Cells were cultured in DMEM supplemented with $10 \%$ fetal bovine serum (FBS) and $1 \%$ antibiotics at $37^{\circ} \mathrm{C}$ in a $5 \% \mathrm{CO}_{2}$ incubator. Isomers of guggulsterone were obtained from Steraloids Inc. (Newport, RI, USA) and dissolved in dimethyl sulfoxide (DMSO). TPA, 3-(4,5-dimethyl-thiazol-2-yl)-2,5-diphenyltetrazoliumbromide (MTT), and anti- $\beta$-actin antibodies were from Sigma (St. Louis, MO, USA). Antibodies against $\mathrm{p}-\mathrm{I} \kappa \mathrm{B} \alpha$, p-IKK $\alpha \beta$, p38, p-p38, JNK, p-JNK, ERK and p-ERK were from Cell Signaling Technology (Beverly, MA, USA). MMP-9, p50, p65, proliferating cell nuclear antigen (PCNA) and horseradish peroxidase (HRP)-conjugated IgG antibodies were from Santa Cruz Biotechnology Inc. (Santa Cruz, CA, USA). High glucosecontaining DMEM, FBS and phosphate-buffered saline (PBS) were purchased from Gibco-BRL (Gaithersburg, MD, USA).

Determination of cell viability. The effect of guggulsterone on MCF-7 cell viability was determined using an MTT assay (26). Briefly, cells were seeded at $3 \times 10^{4}$ cells/well and allowed to attach. After $24 \mathrm{~h}$, cells were treated with guggulsterone at 5,10 or $20 \mu \mathrm{M}$. After incubation for $24 \mathrm{~h}$, cells were washed with PBS. MTT $(0.5 \mathrm{mg} / \mathrm{ml}$ PBS) was then added to each well, and the plates were incubated at $37^{\circ} \mathrm{C}$ for $30 \mathrm{~min}$. Formazan crystals were dissolved with DMSO (100 $\mu \mathrm{l} /$ well), and an intensity of color was detected at $570 \mathrm{~nm}$ using a microplate reader (Model 3550; Bio-Rad, Richmond, CA, USA).

Western blot analysis. MCF-7 cells $\left(5 \times 10^{5}\right)$ were pre-treated with guggulsterone (10 and $20 \mu \mathrm{M})$ for $1 \mathrm{~h}$ and then incubated with TPA for $24 \mathrm{~h}$. Cells were lysed with an ice-cold lysis buffer (50 mM Tris- $\mathrm{HCl}, \mathrm{pH} 7.4,1 \% \mathrm{NP}-40,0.5 \%$ sodium deoxycholate, $150 \mathrm{mM} \mathrm{NaCl}, 1 \mathrm{mM}$ EGTA, $0.1 \%$ SDS). Protein concentration was determined using the Bradford method (27). Samples $(20 \mu \mathrm{g})$ were separated by SDS-PAGE with $10 \%$ acrylamide, and the resolved proteins were transferred onto a hybond-PVDF membrane using a western blotting apparatus. The PVDF membrane was incubated with $2 \%$ bovine serum albumin or $5 \%$ skim milk to block non-specific sites, and then incubated overnight with $1 \mu \mathrm{g} / \mathrm{ml}$ primary antibody for MMP-9, p38, p-p38, JNK, p-JNK, ERK, p-ERK, $\beta$-actin, p50, p65, or PCNA. HRP-conjugated IgG was used as the secondary antibody. Protein expression levels were determined by signal analysis using an image analyzer (Fujifilm, Tokyo, Japan).

Gelatin zymography assay. The conditioned medium was collected after $24 \mathrm{~h}$ of stimulation with TPA, mixed with nonreducing sample buffer, and separated on a polyacrylamide gel containing $0.1 \%(\mathrm{w} / \mathrm{v})$ gelatin (25). Gels were washed at room temperature for $30 \mathrm{~min}$ with $2.5 \%$ Triton $\mathrm{X}-100$ solution, and incubated at $37^{\circ} \mathrm{C}$ for $16 \mathrm{~h}$ in $5 \mathrm{mM} \mathrm{CaCl}_{2}, 0.02 \%$ Brij and $50 \mathrm{mM}$ Tris- $\mathrm{HCl}(\mathrm{pH} 7.5)$. The gel was stained for 30 min with $0.25 \%(\mathrm{w} / \mathrm{v})$ Coomassie brilliant blue in $40 \%(\mathrm{v} / \mathrm{v})$ methanol/7\% (v/v) acetic acid and photographed with an image analyzer (Fujifilm). Proteolysis was imaged as a white zone in a dark blue field. Densitometric analysis was performed using Multi Gauge Image Analysis software (Fujifilm).

Quantitative real-time PCR assay. Total RNA was extracted from the cells using a FastPure RNA kit (Takara Bio Inc., Shiga, Japan). The RNA concentration and purity were determined by absorbance at $260 / 280 \mathrm{~nm}$. cDNA was then synthesized from $1 \mu \mathrm{g}$ total RNA using the PrimeScript RT reagent kit (Takara Bio Inc.). MMP-9 and GAPDH mRNA expression were determined by real-time PCR using the ABI PRISM 7900 sequence detection system and SYBR ${ }^{\circledR}$-Green (Applied Biosystems, Foster City, CA, USA). Primers used were: MMP-9 (NM-004994) sense, CCTGGAGACCTGAGAACC AATCT and antisense, CCACCCGAGTGTAACCATAGC; and GAPDH (NM-002046) sense, ATGGAAATCCCATC ACCATCTT and antisense, CGCCCCACTTGATTTTGG. To control for variation in mRNA concentration, all the results were normalized to the housekeeping gene, GAPDH. Relative quantification was performed using the comparative $\Delta \Delta \mathrm{Ct}$ method according to the manufacturer's instructions.

Preparation of nuclear extract. The MCF-7 cells $\left(2 \times 10^{6}\right)$ were treated with guggulsterone in the presence or absence of TPA for 4 h. Cells were immediately washed twice with PBS ( $\mathrm{pH} 7.5$ ), scraped into $1.5 \mathrm{ml}$ of ice-cold PBS, and pelleted at $1,500 \mathrm{x} \mathrm{g}$ for $3 \mathrm{~min}$. Cytoplasmic and nuclear extracts were prepared from cells using the NE-PER ${ }^{\circledR}$ Nuclear and Cytoplasmic Extraction Reagents (Pierce Biotechnology, Rockford, IL, USA).

Electrophoretic mobility shift assay (EMSA). The activation of NF- $\kappa \mathrm{B}$ and AP-1 was assayed with a gel mobility shift assay using nuclear extracts. An oligonucleotide containing the $\kappa$-chain ( $\mathrm{B}, 5$ '-CCGGTTAACAGAGGGGGCTTTCCG AG-3') or the AP-1 (5'-CGCTTGATGAGTCAGCCGGAA-3') binding site was synthesized and used as a probe for gel retardation assay. Two complementary strands were annealed and labeled with $\left[\alpha-{ }^{32} \mathrm{P}\right] \mathrm{dCTP}$. Labeled oligonucleotides $(10,000 \mathrm{cpm}), 10 \mu \mathrm{g}$ of nuclear extracts, and a binding buffer [10 mM Tris- $\mathrm{HCl}, \mathrm{pH}$ 7.6, $500 \mathrm{mM} \mathrm{KCl,} 10 \mathrm{mM}$ EDTA, 50\% glycerol, $100 \mathrm{ng}$ poly $(\mathrm{dI} \cdot \mathrm{dC}), 1 \mathrm{mM}$ DTT] were incubated for $30 \mathrm{~min}$ at room temperature in a final volume of $20 \mu \mathrm{l}$. Reaction mixtures were analyzed by electrophoresis on $4 \%$ polyacrylamide gels in $0.5 \mathrm{X}$ TBE buffer (final concentrations: $22.5 \mathrm{mM}$ Tris-borate, $\mathrm{pH}$ 7.6, $0.5 \mathrm{mM}$ EDTA). Gels were dried and 


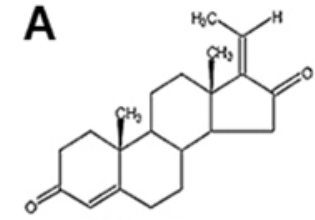

cis-guggulsterone

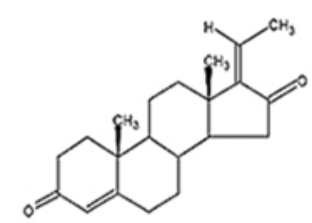

trans-guggulsterone

B

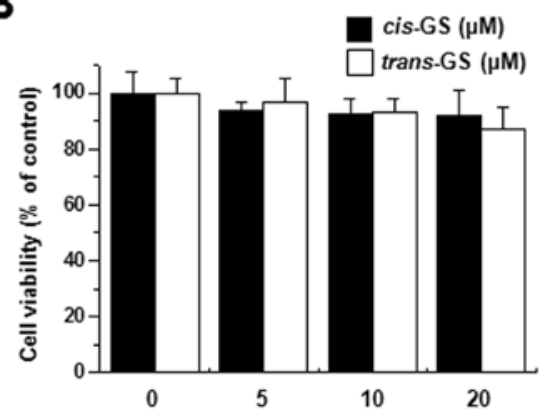

Figure 1. Effect of guggulsterone on the cell viability of MCF-7 cells. (A) Chemical structure of guggulsterone. For the cytotoxicity test, cells were cultured in 96-well plates to $70 \%$ confluency and treated with various guggulsterone concentrations $(5,10$ and $20 \mu \mathrm{M})$ for $24 \mathrm{~h}$. (B) MTT assay was used to detect cell viability. The optical density of the controls was regarded as $100 \%$. Data are presented as the means \pm SEM of three independent experiments.

examined by autoradiography. Specific binding was controlled by competition with a 50 -fold excess of cold $\kappa \mathrm{B}$ or AP-1 oligonucleotide.

Invasion assay. Invasion assays were carried out in 24-well chambers (8- $\mu \mathrm{m}$ pore size) coated with $20 \mu \mathrm{l}$ Matrigel diluted in DMEM. The Matrigel coating was re-hydrated in $0.5 \mathrm{ml}$ DMEM for $30 \mathrm{~min}$ immediately before the experiments. Cells $\left(2 \times 10^{5}\right.$ cells/well $)$ were added to the upper chamber with chemoattractant in the bottom well. Conditioned medium $(0.5 \mathrm{ml})$ was added to the lower compartment of the invasion chamber and chambers were incubated for $24 \mathrm{~h}$. Following incubation, cells on the upper side of the chamber were removed using cotton swabs, and cells that had migrated were fixed and stained with toluidine blue solution. Invaded cells were counted in five random areas of the membrane under a light microscope. Data are presented as the means \pm SE from three individual experiments performed in triplicate.

Statistical analysis. Statistical analysis was performed using ANOVA and Duncan's test. A value of $\mathrm{P}<0.05$ was considered to indicate a statistically significant difference.

\section{Results}

Effect of guggulsterone isomers on MCF-7 cell viability. Since the cytotoxicity of guggulsterone $c i s$ - and trans-isomers (Fig. 1A) on MCF-7 cells has not been previously reported, we examined the cytotoxicity to avoid interference from the reagent. The treatment of MCF-7 cells with guggulsterone isomers $(5,10$ and $20 \mu \mathrm{M})$ for $24 \mathrm{~h}$ caused no significant change in cell viability (Fig. 1B).
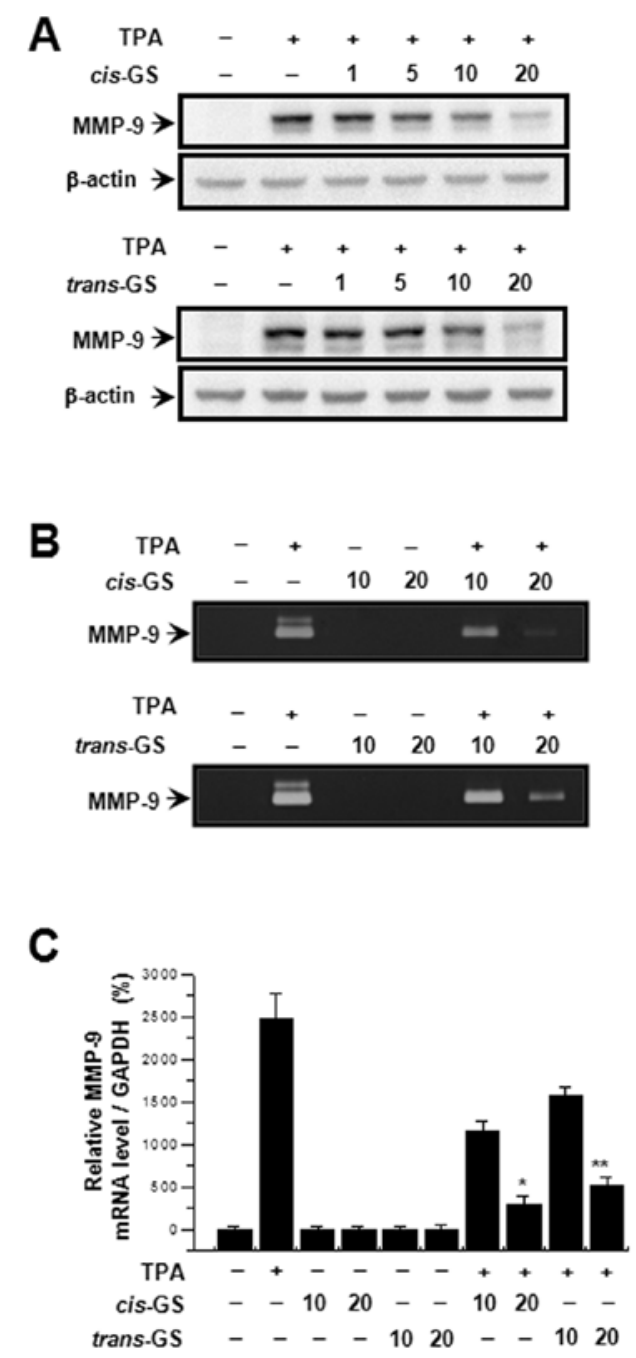

Figure 2. Guggulsterone inhibits TPA-induced MMP-9 expression in MCF-7 cells. MCF-7 cells $\left(5 \times 10^{5}\right)$ in monolayer were treated with the indicated guggulsterone concentrations in the presence of $100 \mathrm{nM}$ TPA for $24 \mathrm{~h}$. Cell lysates were analyzed by western blot analysis with anti-MMP-9 antibody. (A) The blot was reprobed with anti- $\beta$-actin to confirm equal loading. (B) Conditioned medium was prepared and used for gelatin zymography. (C) MMP-9 mRNA levels were analyzed by real-time PCR and GAPDH was used as the internal control. Each value represents the mean \pm SEM of three independent experiments. ${ }^{*} \mathrm{P}<0.01$ vs. TPA; ${ }^{* *} \mathrm{P}<0.05$ vs. TPA.

Effect of guggulsterone isomers on TPA-induced MMP-9 expression in MCF-7 cells. In order to investigate the effect of guggulsterone on TPA-induced MMP-9 expression, we performed western blot analysis, real-time PCR, and zymography with MCF-7 cells. MCF-7 cells were treated with guggulsterone isomers $(1,5,10$ and $20 \mu \mathrm{M})$ in the presence of $100 \mathrm{nM}$ TPA for $24 \mathrm{~h}$. Western blot analysis revealed that the treatment of MCF cells with guggulsterone isomers blocked the upregulation of TPA-induced MMP-9 expression in a concentration-dependent manner (Fig. 2A). Determination of the effects of guggulsterone isomers on TPA-induced MMP-9 secretion revealed that both $c$ is-and trans-isomers substantially inhibited TPA-induced MMP-9 secretion (Fig. 2B). Real-time PCR also showed that TPA increased the MMP-9 mRNA levels in MCF-7 cells, which was blocked by guggulsterone isomers in a dose-dependent manner (Fig. 2C). Of note, cis-gugulsterone decreased MMP-9 expression and secretion to a greater extent 

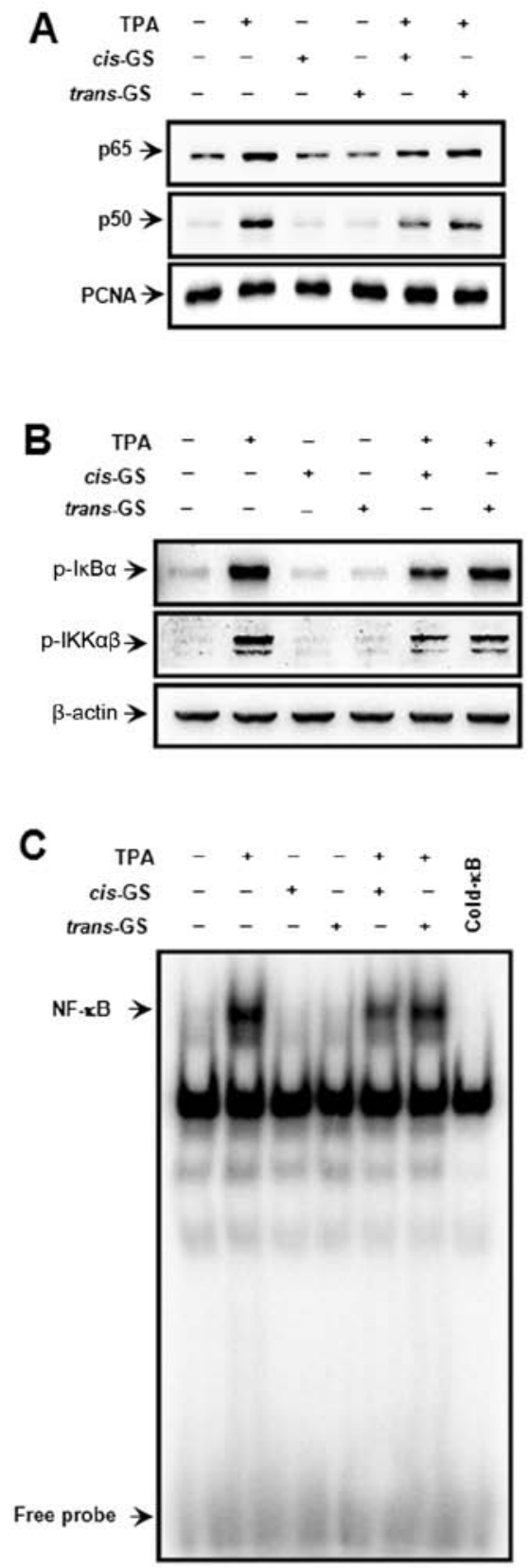

Figure 3. Guggulsterone blocks TPA-induced IKK/NF- $\mathrm{KB}$ activation in MCF-7 cells. Cells were treated with $20 \mu \mathrm{M}$ guggulsterone isomers in the presence of $100 \mathrm{nM}$ TPA. After $3 \mathrm{~h}$ of incubation, nuclear extracts were prepared. (A) p65 and p50 translocation to the nucleus and (B) phosphorylation of

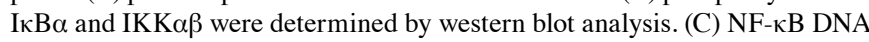
binding was analyzed by electrophoretic mobility shift analysis as described in Materials and methods.

at $20 \mu \mathrm{M}$ than trans-guggulsterone (Fig. 2A and B). These results indicate that the cis-isomer is more potent than the trans-isomer in the inhibition of TPA-induced MMP-9 expression and secretion in MCF-7 cells.

Effect of guggulsterone isomers on TPA-induced $N F-\kappa B$ activation. The MMP-9 promoter contains NF- $\mathrm{KB}$ and AP-1 binding sites, both of which are centrally involved in MMP-9 gene induction $(23,24,28,29)$. To investigate the transcription factor involved in inhibiting MMP-9 transcription by guggulsterone, we first examined the effect of guggulsterone isomers on the TPA-stimulated NF- $\mathrm{KB}$ signaling pathway.

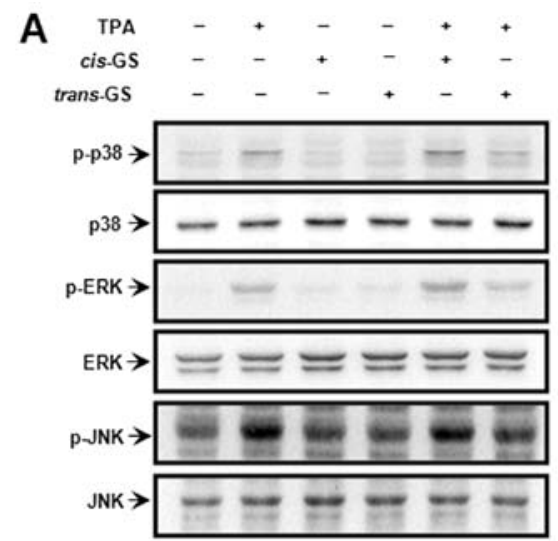

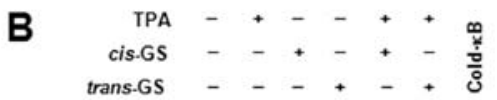

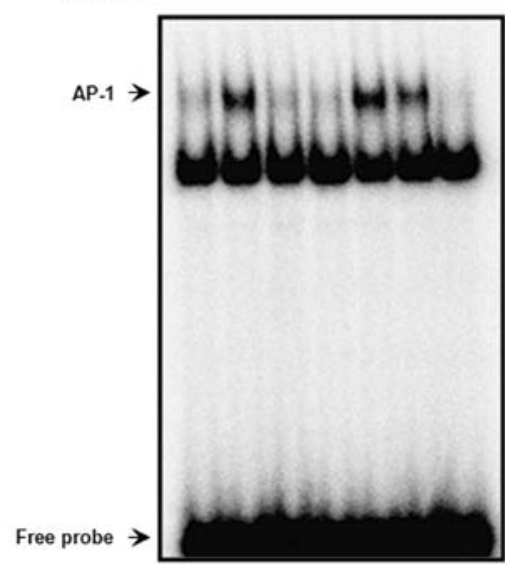

Figure 4. Guggulsterone blocks TPA-induced MAPK/AP-1 activation in MCF-7 cells. Cells were treated with $20 \mu \mathrm{M}$ guggulsterone isomers in the presence of $100 \mathrm{nM}$ TPA. (A) After $30 \mathrm{~min}$ of incubation, cell lysates were prepared for western blot analysis with specific p-p38, p38, p-JNK, JNK, p-ERK and ERK antibodies. Cells were treated with $20 \mu \mathrm{M}$ guggulsterone isomers in the presence of $100 \mathrm{nM}$ TPA. (B) After $4 \mathrm{~h}$ of incubation, nuclear extracts were prepared and examined for AP-1 DNA binding activity by electrophoretic mobility shift analysis as described in Materials and methods.

The treatment of MCF-7 cells with guggulsterone isomers revealed that $c i s$-isomer, but not trans-isomer, inhibited the TPA-stimulated nuclear translocation of $\mathrm{p} 65 / \mathrm{p} 50$, an NF- $\mathrm{KB}$ subunit and NF- $\kappa$ B DNA binding activity (Fig. $3 \mathrm{~A}$ and $\mathrm{C}$ ), as well as the TPA-induced phosphorylation of IкB $\alpha$ (Ser-32) and IKK $\alpha \beta$ (Ser-176/180) (Fig. 3B). These data indicate that inhibition of the TPA-stimulated activation of the IKK/IKB/ $\mathrm{NF}-\mathrm{\kappa B}$ axis by guggulsterone is stereoisomer-specific and that cis-guggulsterone is an inhibitor of IKK.

Effect of guggulsterone isomers on TPA-induced AP-1 activation. MAPK signaling pathways are involved in the AP-1 transcriptional activity (29). We investigated the effect of guggulsterone on the TPA-induced activation of MAPK and AP-1 by western blot analysis and EMSA. The TPA-induced ERK, JNK and p38 phosphorylation, and the activation of AP-1 binding activity were detected (Fig. 4). The activation of the signaling molecules by TPA was significantly blocked by trans-guggulsterone, but not cis-guggulsterone, indicating that the inhibition of TPA-stimulated AP-1 activa- 

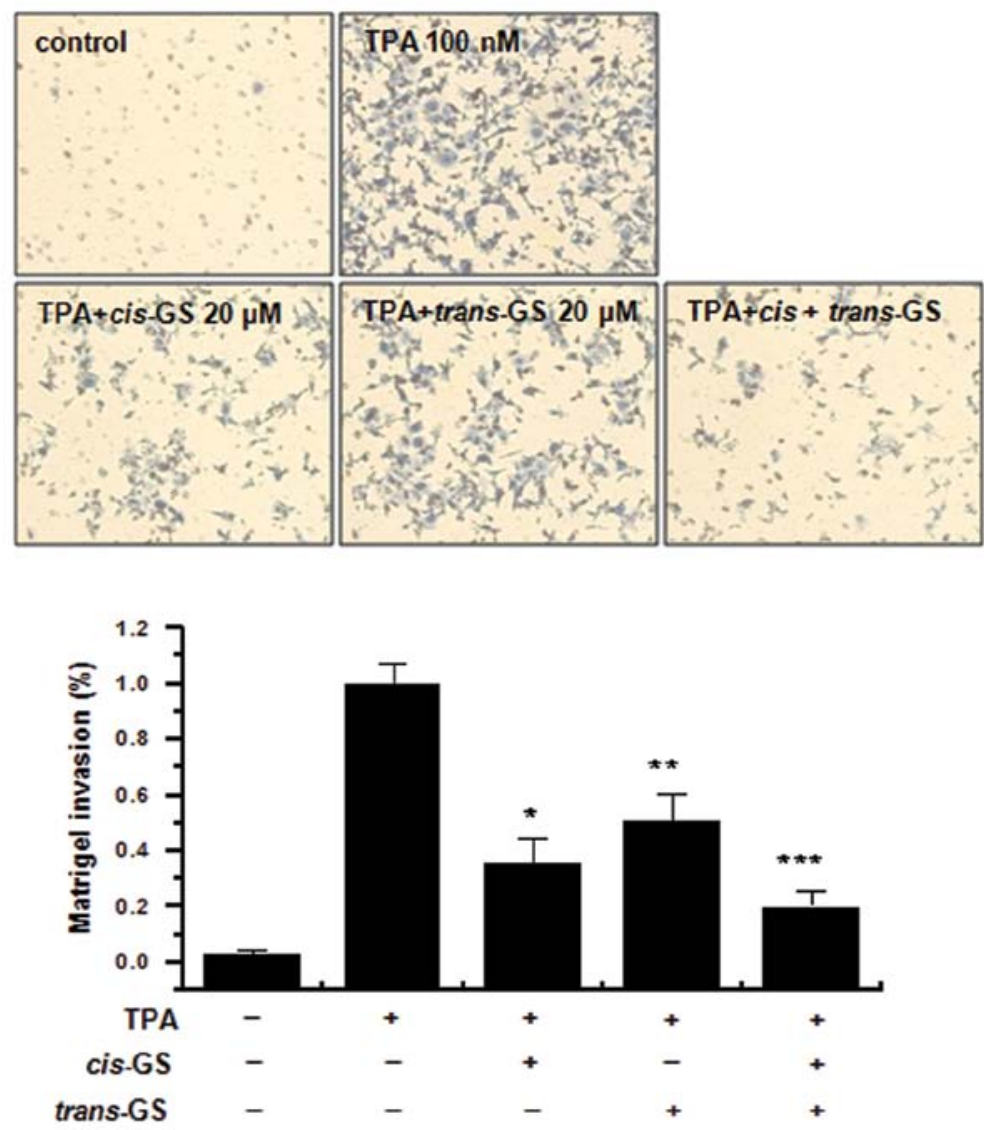

Figure 5. Effect of guggulsterone on TPA-induced Matrigel invasion of MCF-7 cells. Cells were seeded onto the upper chamber and drugs were placed in the well. After $24 \mathrm{~h}$ of incubation, cells at the bottom of the filter were fixed, stained and counted. Each value represents the mean \pm SEM of three independent experiments. ${ }^{*} \mathrm{P}<0.01$ vs. TPA; ${ }^{* *} \mathrm{P}<0.01$ vs. TPA; and ${ }^{* * *} \mathrm{P}<0.01$ vs. TPA.

tion by guggulsterone is also stereoisomer-specific; that is, trans-guggulsterone regulates TPA-mediated MAPK/AP-1 activation in MCF-7 cells.

Effect of guggulsterone isomers on TPA-induced MCF-7 cell invasion in vitro. The effects of guggulsterone isomers on the invasive potential of MCF-7 breast cancer cells were evaluated using a Matrigel invasion assay. Treatment with TPA increased MCF-7 cell invasion compared to the control MCF-7 cells. The incubation of MCF-7 cells with TPA resulted in a 10-fold increase in the invasion of MCF-7 cells. Treatment with cisguggulesterone decreased the TPA-induced cell invasion by $67 \%$, and the trans-isomer reduced the invasion by $51 \%$ (Fig. 5). The combination of these isomers exerted an additive effect on the inhibition of MCF-7 cell invasion, showing a 79\% inhibition of invasion.

\section{Discussion}

This study examined the effects of guggulsterone isomers (cis and trans) on TPA-induced cell invasion, MMP-9 expression and related molecular mechanisms in MCF-7 cells. We found that cis-guggulsterone inhibited TPA-induced MMP expression by blocking IKK/NF- $\mathrm{BB}$ signaling, whereas trans-guggulsterone by blocking MAPK/AP-1 signaling, suggesting that guggulsterone isomers differ in the modulation of TPA-induced MMP-9 expressions in MCF-7 cells. The combination of isomers exerted additive effects on the inhibition of MCF-7 cell invasion. This study is the first to show that the combination of guggulsterone isomers may be a potential therapeutic strategy for breast cancer.

$\mathrm{NF}-\kappa \mathrm{B}$ is a transcription factor that plays an important role in the induction of MMP-9 gene expression $(30,31)$. NF- $\kappa \mathrm{B}$ comprises a family of inducible transcription factors which regulate host inflammatory and immune responses (32). Diverse signal transduction cascades mediate $\mathrm{NF}-\kappa \mathrm{B}$ pathway stimulation (32). NF- $\kappa \mathrm{B}$ is an inducible dimeric transcription factor that belongs to the Rel/NF- $\kappa \mathrm{B}$ family of transcription factors and consists of two major polypeptides, p65 and p50 (33). $\mathrm{NF}-\kappa \mathrm{B}$ is initially located in the cytoplasm in an inactive form complexed with $\mathrm{I} \kappa \mathrm{B}$, an inhibitory factor of $\mathrm{NF}-\kappa \mathrm{B}$. Various inducers such as TPA, cytokines and stress can dissociate this complex, presumably by $\mathrm{I} \kappa \mathrm{B}$ phosphorylation, resulting in $\mathrm{NF}-\kappa \mathrm{B}$ being released from the complex. IKK $\alpha \beta$ phosphorylates serine residues in the $\mathrm{NH}_{2}$-terminus of $\mathrm{I} \kappa \mathrm{B}$, resulting in $\mathrm{NF}-\kappa \mathrm{B}$ release and translocation to the nucleus (30). NF- $\kappa \mathrm{B}$ then translocates to the nucleus, where it interacts with specific DNA recognition sites to mediate gene transcription. The $\mathrm{NF}-\kappa \mathrm{B}$ elements are centrally involved in MMP-9 gene induction by TPA $(23,34)$. Shishodia and Aggarwal (6) showed that guggulsterone suppressed NF- $\mathrm{B}$ activation by inhibiting IKK and $\mathrm{I} \kappa \mathrm{B} \alpha$ degradation in the majority of tumor cells. In support of these observations, we found that the TPA-stimulated phosphorylation of IKK $\alpha \beta$ and I $\mathrm{I} B \alpha$ and the nuclear translocation of $\mathrm{NF}-\kappa \mathrm{B}$ were inhibited by treatment with cis-guggulsterone, 
but not with trans-guggulsterone. These findings suggest that cis-guggulsterone is a specific inhibitor of the IKK/NF- $\mathrm{BB}$ pathway.

AP-1 is a sequence-specific transcriptional factor composed of Jun, Fos and ATF family proteins, which are induced by multiple stimuli such as TPA, cytokines, growth factors and stress (35). The MAPK signaling pathway plays a pivotal role in AP-1 activation (17-21). The activation of ERK results in an increase in AP-1 activity via c-Fos induction, whereas JNK activation leads to the c-Jun phosphorylation (17-21). In this study, the results showed that TPA-induced ERK, JNK and p38 phosphorylation, and AP-1 binding activity via c-Fos induction were blocked by trans-guggulsterone, but not by $c i s$ guggulsterone. These findings suggest that trans-guggulsterone is a specific inhibitor of the MAPK/AP-1 pathway.

MMP-9 activation has been shown to be associated with the progression and invasion of tumors, including mammary tumors (36). Thus, the discovery and development of an agent that inhibits MMP-9 expression are important for the treatment of cancer/tumors. Guggulesterone significantly diminished the TPA-induced cell invasion, and the combination of these isomers exerted additive effects on the inhibition of MCF-7 cell invasion. These results indicate that MMP-9 may be one of the critical molecules involved in processing tumor invasion and metastasis of breast cancer cells.

In conclusion, guggulsterone isomers downregulate MMP-9 expression and tumor cell invasion through the stereoisomerspecific suppression of IKK/NF- $\kappa \mathrm{B}$ and MAPK/AP-1 activation. That is, cis-guggulsterone regulates the IKK/NF- $\mathrm{BB}$ pathway and trans-guggulsterone regulates MAPK/AP-1 activation. Therefore, guggulsterone isomers modulate TPA-induced MMP-9 expression in MCF-7 cells in an isomer-specific manner. Moreover, the combination of these isomers exerts an additive effect on inhibition of MCF-7 cell invasion. Based on these observations, we suggest that the combination of cis- and trans-guggulsterone isomers may be a strong candidate for the prevention of breast tumor invasion and metastasis.

\section{Acknowledgements}

This study was supported by the Korea Science and Engineering Foundation (KOSEF) (nos. R11-2002-100-04001-0 and M10528010003-05N2801-00310), and the Korea Research Foundation Grant (nos. KRF-2009-0076698 and KRF-20100012716), Republic of Korea.

\section{References}

1. Sinal CJ and Gonzalez FJ: Guggulsterone: an old approach to a new problem. Trends Endocrinol Metab 13: 275-276, 2002.

2. Urizar NL and Moore DD: GUGULIPID: a natural cholesterollowering agent. Annu Rev Nutr 23: 303-313, 2003.

3. Yang JY, Della-Fera MA and Baile CA: Guggulsterone inhibits adipocyte differentiation and induces apoptosis in 3T3-L1 cells Obesity (Silver Spring) 16: 16-22, 2008.

4. Shishodia S, Sethi G, Ahn KS and Aggarwal BB: Guggulsterone inhibits tumor cell proliferation, induces S-phase arrest, and promotes apoptosis through activation of c-Jun N-terminal kinase, suppression of Akt pathway, and downregulation of antiapoptotic gene products. Biochem Pharmacol 74: 118-130, 2007.

5. Satyavati GV: Gum guggul (Commiphora mukul) - the success story of an ancient insight leading to a modern discovery. Indian J Med Res 87: 327-335, 1988.
6. Shishodia S and Aggarwal BB: Guggulsterone inhibits NF-kappaB and IkappaBalpha kinase activation, suppresses expression of anti-apoptotic gene products, and enhances apoptosis. J Biol Chem 279: 47148-47158, 2004.

7. Cheon JH, Kim JS, Kim JM, Kim N, Jung HC and Song IS: Plant sterol guggulsterone inhibits nuclear factor-kappaB signaling in intestinal epithelial cells by blocking IkappaB kinase and ameliorates acute murine colitis. Inflamm Bowel Dis 12: 1152-1161, 2006.

8. Ichikawa H and Aggarwal BB: Guggulsterone inhibits osteoclastogenesis induced by receptor activator of nuclear factor-kappaB ligand and by tumor cells by suppressing nuclear factor-kappaB activation. Clin Cancer Res 12: 662-668, 2006.

9. Woessner JF Jr: Matrix metalloproteinases and their inhibitors in connective tissue remodeling. FASEB J 5: 2145-2154, 1991.

10. Nakajima M, Welch DR, Belloni PN and Nicolson GL: Degradation of basement membrane type IV collagen and lung subendothelial matrix by rat mammary adenocarcinoma cell clones of differing metastatic potentials. Cancer Res 47: 4869-4876, 1987.

11. Egeblad M and Werb Z: New functions for the matrix metalloproteinases in cancer progression. Nat Rev Cancer 2: 161-174, 2002.

12. Saito N, Hatori T, Murata N, et al: A double three-step theory of brain metastasis in mice: the role of the pia mater and matrix metalloproteinases. Neuropathol Appl Neurobiol 33: 288-298, 2007.

13. Castellano G, Malaponte G, Mazzarino MC, et al: Activation of the osteopontin/matrix metalloproteinase-9 pathway correlates with prostate cancer progression. Clin Cancer Res 14: 7470-7480, 2008.

14. Kanayama H: Matrix metalloproteinases and bladder cancer. J Med Invest 48: 31-43, 2001.

15. Lin CW, Hou WC, Shen SC, et al: Quercetin inhibition of tumor invasion via suppressing PKC delta/ERK/AP-1-dependent matrix metalloproteinase-9 activation in breast carcinoma cells. Carcinogenesis 29: 1807-1815, 2008.

16. Lee SO, Jeong YJ, Kim M, Kim CH and Lee IS: Suppression of PMA-induced tumor cell invasion by capillarisin via the inhibition of NF-kappaB-dependent MMP-9 expression. Biochem Biophys Res Commun 366: 1019-1024, 2008.

17. Yao J, Xiong S, Klos K, et al: Multiple signaling pathways involved in activation of matrix metalloproteinase-9 (MMP-9) by heregulin-betal in human breast cancer cells. Oncogene 20: 8066-8074, 2001.

18. Ruhul Amin AR, Senga T, Oo ML, Thant AA and Hamaguchi M: Secretion of matrix metalloproteinase- 9 by the proinflammatory cytokine, IL-1beta: a role for the dual signalling pathways, Akt and Erk. Genes Cells 8: 515-523, 2003.

19. Karin M: The regulation of AP-1 activity by mitogen-activated protein kinases. J Biol Chem 270: 16483-16486, 1995.

20. Madrid LV, Mayo MW, Reuther JY and Baldwin AS Jr: Akt stimulates the transactivation potential of the RelA/p65 Subunit of NF-kappa B through utilization of the Ikappa B kinase and activation of the mitogen-activated protein kinase p38. J Biol Chem 276: 18934-18940, 2001.

21. Weng CJ, Chau CF, Hsieh YS, Yang SF and Yen GC: Lucidenic acid inhibits PMA-induced invasion of human hepatoma cells through inactivating MAPK/ERK signal transduction pathway and reducing binding activities of NF-kappaB and AP-1. Carcinogenesis 29: 147-156, 2008.

22. Nabeshima K, Inoue T, Shimao Y and Sameshima T: Matrix metalloproteinases in tumor invasion: role for cell migration. Pathol Int 52: 255-264, 2002.

23. Hong S, Park KK, Magae J, et al: Ascochlorin inhibits matrix metalloproteinase- 9 expression by suppressing activator protein1-mediated gene expression through the ERK1/2 signaling pathway: inhibitory effects of ascochlorin on the invasion of renal carcinoma cells. J Biol Chem 280: 25202-25209, 2005.

24. Woo MS, Jung SH, Kim SY, et al: Curcumin suppresses phorbol ester-induced matrix metalloproteinase- 9 expression by inhibiting the PKC to MAPK signaling pathways in human astroglioma cells. Biochem Biophys Res Commun 335: 1017-1025, 2005.

25. Kim KH, Park BH, Tu Y, et al: Polarization-sensitive optical frequency domain imaging based on unpolarized light. Opt Express 19: 552-561, 2011.

26. Plumb JA, Milroy R and Kaye SB: Effects of the $\mathrm{pH}$ dependence of 3-(4,5-dimethylthiazol-2-yl)-2,5-diphenyl-tetrazolium bromide-formazan absorption on chemosensitivity determined by a novel tetrazolium-based assay. Cancer Res 49: 4435-4440, 1989. 
27. Bradford MM: A rapid and sensitive method for the quantitation of microgram quantities of protein utilizing the principle of protein-dye binding. Anal Biochem 72: 248-254, 1976.

28. Azuma M, Aota K, Tamatani T, et al: Suppression of tumor necrosis factor alpha-induced matrix metalloproteinase 9 production in human salivary gland acinar cells by cepharanthine occurs via down-regulation of nuclear factor kappaB: a possible therapeutic agent for preventing the destruction of the acinar structure in the salivary glands of Sjogren's syndrome patients. Arthritis Rheum 46: 1585-1594, 2002.

29. Hwang YP, Yun HJ, Kim HG, Han EH, Lee GW and Jeong HG: Suppression of PMA-induced tumor cell invasion by dihydroartemisinin via inhibition of PKCalpha/Raf/MAPKs and NF-kappaB/AP-1-dependent mechanisms. Biochem Pharmacol 79: 1714-1726, 2010.

30. Eberhardt W, Huwiler A, Beck KF, Walpen S and Pfeilschifter J: Amplification of IL-1 beta-induced matrix metalloproteinase- 9 expression by superoxide in rat glomerular mesangial cells is mediated by increased activities of NF-kappaB and activating protein- 1 and involves activation of the mitogen-activated protein kinase pathways. J Immunol 165: 5788-5797, 2000.
31. Lungu G, Covaleda L, Mendes O, Martini-Stoica H and Stoica G: FGF-1-induced matrix metalloproteinase-9 expression in breast cancer cells is mediated by increased activities of NF-kappaB and activating protein-1. Mol Carcinog 47: 424-435, 2008.

32. Yamamoto Y and Gaynor RB: Therapeutic potential of inhibition of the NF-kappaB pathway in the treatment of inflammation and cancer. J Clin Invest 107: 135-142, 2001.

33. Thanos D and Maniatis T: NF-kappa B: a lesson in family values. Cell 80: 529-532, 1995.

34. Chung TW, Moon SK, Chang YC, et al: Novel and therapeutic effect of caffeic acid and caffeic acid phenyl ester on hepatocarcinoma cells: complete regression of hepatoma growth and metastasis by dual mechanism. FASEB J 18: 1670-1681, 2004.

35. Bakiri L, Matsuo K, Wisniewska M, Wagner EF and Yaniv M: Promoter specificity and biological activity of tethered AP-1 dimers. Mol Cell Biol 22: 4952-4964, 2002.

36. Scorilas A, Karameris A, Arnogiannaki N, et al: Overexpression of matrix-metalloproteinase-9 in human breast cancer: a potential favourable indicator in node-negative patients. Br J Cancer 84: 1488-1496, 2001 